\title{
A lipidated peptide of Mycobacterium tuberculosis resuscitates the protective efficacy of BCG vaccine by evoking memory T cell immunity
}

Pradeep K. Rai', Sathi Babu Chodisetti ${ }^{1,2}$, Weiguang Zeng ${ }^{3}$, Sajid Nadeem', Sudeep K. Maurya', Susanta Pahari ${ }^{1}$, Ashok K. Janmeja ${ }^{4}$, David C. Jackson ${ }^{3}$ and Javed N. Agrewala ${ }^{1^{*}}$

\begin{abstract}
Background: The current BCG vaccine induces only short-term protection against Mycobacterium tuberculosis (Mtb), suggesting its failure to generate long-lasting memory $T$ cells. Previously, we have demonstrated that a self-adjuvanting peptide of Mtb (L91), successfully generated enduring memory Th1 cells. Consequently, we investigated if L91 was able to recuperate BCG potency in perpetuating the generation of memory T cells and protection against Mtb infected mice.

Methods: In the present study, we evaluated the potency of a self adjuvanting Mtb peptide vaccine $L 91$ in invigorating BCG immune response against $M t b$ in mice. Female BALB/C mice were immunized with BCG. Later, they were boosted twice with $L 91$ or an antigenically irrelevant lipidated influenza virus hemagglutinin peptide (LH). Further, PBMCs obtained from BCG vaccinated healthy subjects were cultured in vitro with L91. T cell responses were determined by surface markers and intracellular cytokine staining. Secretion of cytokines was estimated in the culture supernatants (SNs) by ELISA.

Results: Compared to the BCG-vaccinated controls, L91 booster significantly enhanced the percentage of memory Th1 cells and Th17 cells and reduced the mycobacterial burden in BCG primed and L91-boosted (BCG-L91) group, even after 229 days of BCG vaccination. Further, substantial augmentation in the central (CD44 ${ }^{\text {hi }} C D 62 L^{\text {hi }} C D 127^{\text {hi }}$ ) and effector memory $\left(\mathrm{CD} 44^{\mathrm{hi}} \mathrm{CD} 62 \mathrm{~L}^{\mathrm{lo}} \mathrm{CD} 127^{\mathrm{l}}\right) \mathrm{CD} 4 \mathrm{~T}$ cells was detected. Furthermore, greater frequency of polyfunctional Th1 cells $\left(\right.$ IFN- ${ }^{+}$TNF- $\left.a^{+}\right)$and Th17 cells $\left(I F N-\gamma^{+} \mid \mathrm{L}-17 \mathrm{~A}^{+}\right)$was observed. Importantly, BCG-L91 successfully prevented CD4 T cells from exhaustion by decreasing the expression of PD-1 and Tim-3. Additionally, augmentation in the frequency of Th1 cells, Th17 cells and memory CD4T cells was observed in the PBMCs of the BCG-vaccinated healthy individuals following in vitro stimulation with L91.

Conclusions: Our study demonstrated that L91 robustly reinvigorate BCG potency to invoke enduring protection against Mtb. This novel vaccination stratagem involving BCG-priming followed by L91-boosting can be a future prophylactic measure to control TB.
\end{abstract}

Keywords: Vaccine, BCG, L91,TB, Mtb, Th1, Th17, Memory T cells

\section{Background}

Tuberculosis (TB) is a deadly disease infecting 9.6 million people globally and accounts for 1.5 million deaths

\footnotetext{
${ }^{*}$ Correspondence: javed@imtech.res.in

${ }^{1}$ CSIR-Institute of Microbial Technology, Chandigarh, India

Full list of author information is available at the end of the article
}

annually [1]. Currently, BCG is the only available vaccine against TB, which is administered since 1974 under immunization program of World Health Organization (WHO) [2, 3]. Unfortunately, continuous increase in the number of TB cases raises a question on the protective efficacy of BCG [4-6]. Interestingly, BCG protects children from TB [7], indicating that it has adequate 
antigenic repertoire to protect against Mycobacterium tuberculosis $(M t b)$. In contrast, it fails to safeguard adults from TB; which has been suggested to be due to its failure to generate long-lasting memory $\mathrm{T}$ cells [8].

Many studies are in progress to bolster BCG efficiency to impart enduring immunity. Memory inducing cytokines like IL-7 and IL-15 have been shown to sufficiently augment the BCG induced memory $\mathrm{T}$ cells [8]. Furthermore, booster dose of $M t b$ antigen Acr1 entrapped in fusogenic-liposomes generated long-term memory $\mathrm{T}$ cells and improved BCG potency [9]. Thus, it implies that the protective efficacy of BCG can be boosted through antigen-priming. Recently, we have synthesized a novel lipopeptide vaccine construct L91, which comprises of a promiscuous-peptide derived from Acr1 and the TLR2 agonist Pam2Cys [5, 10]. L91 elicited both innate and adaptive immunity successfully through its Pam2Cys and peptide component, respectively $[5,10]$. TLR-2 promotes the generation of memory $T$ cells, rescued Th1 cells from exhaustion and protected mice from chronic TB [11]. Intriguingly, L91 elicited long-lasting memory $\mathrm{T}$ cells and protected mice and Guinea pigs from $M t b$ infection [10].

In the current study, we have demonstrated that the memory $\mathrm{T}$ cell generation and protection efficacy of BCG vaccine against $M t b$ could be significantly bolstered with L91 boosting of the BCG-vaccinated population. Specifically we observed improvement in the pool of enduring memory Th1 and Th17 responses, the cells that play crucial role in protection against $M t b$. In future, this vaccination strategy may be implemented to protect people from TB.

\section{Methods}

\section{Study design}

Female BALB/c mice (6-8 week) were procured from the Experimental Animal Facility, CSIR-Institute of Microbial Technology, Chandigarh, India. Mice were immunized subcutaneously (sc) at the base of tail with the Danish strain of BCG ( $10^{6} \mathrm{CFU} /$ mouse). Twenty-one days later, BCG-primed mice were boosted twice with L91, at an interval of 14 days apart (BCG-L91). Control groups were immunized with BCG alone (BCG), placebo (PBS) or an antigenically irrelevant lipidated influenza virus hemagglutinin peptide (abbreviated as $\mathrm{LH}$ or Pam2Cys). Mice were aerosol challenged with $M t b$ ( $100 \mathrm{CFU} /$ mouse), 90 days after the last booster. Subsequently, animals were sacrificed after 90 days of $M t b$ challenge. Later, immunological (ex vivo), protection and histopathology studies were performed. To monitor the antigen specific $\mathrm{T}$ cell response, mice were sacrificed 30 days after $M t b$ infection, and cellular responses were examined following in vitro stimulation with L91, Pam2Cys and short term culture filtrate of H37Rv (ST-CF). In all the experiments, changes in the response on vaccination were compared among BCG-L91 and control BCG and placebo (PBS) groups or otherwise indicated.

\section{Vaccine constructs used in study}

Lipidated synthetic peptides used in the study were produced by solid phase synthesis method, as described elsewhere [12]. The lipidated promiscuous peptide of sequence SEFAYGSFVRTVSLPVGADE was from the Acr1 antigen of $M t b$ (L91). The control, non-mycobacterial, lipidated peptide (LH) sequence ALNNRFQIKGVELKS was from influenza virus hemagglutinin light chain and was shown to be active in BALB/c mice [13].

\section{Mycobacterial strains and BCG}

$M t b \mathrm{H} 37 \mathrm{Rv}$ strain was cultured in $7 \mathrm{H} 9$ medium containing Tween-80 (0.05\%), supplemented with albumin (10\%), dextrose and catalase (ADC). Glycerol stocks of H37Rv were prepared and stored at $-80{ }^{\circ} \mathrm{C}$, and later used for infection studies. BCG vaccine (TUBERVAC) used for immunization was purchased from Serum Institute of India, Pune, India. TUBERVAC (Bacillus CalmetteGuerin Vaccine I.P.) is a live freeze-dried vaccine derived from an attenuated strain of Mycobacterium bovis and meets the requirements of $\mathrm{WHO}$ and I.P. when tested by the methods outlined in WHO, TRS. 745 (1987), 771 (1988) and I.P.

\section{Reagents and antibodies}

Chemicals and reagents were purchased from SigmaAldrich (St. Louis, MO). Anti-mouse or anti-human fluorochrome labeled antibodies (Abs): CD4-PB, CD62LAPC, CD44-PerCP-Cy5.5, CD127-PE, FoxP3-FITC, Tim3-PE, PD1-PECy7, IFN- $\gamma$-PECy7, TNF $\alpha$-PerCPCy5.5, IL-17-PerCPCy5.5, CD25APC-Cy7, CD45RA-PE, CD45RO-APC, and Abs for ELISA were procured from BD Pharmingen (San Diego, CA) or otherwise mentioned. RPMI-1640 and FBS were purchased from GIBCO (Grand Island, NY) for cell culture. For culturing of cells, tissue culture grade plastic-wares were purchased from BD Biosciences (Bedford, MA). Ab against iNOS used in Western blot was procured from (Abcam, Cambridge, United Kingdom).

\section{Isolation of lymphocytes from lymph nodes, spleen and lungs}

Spleens and LNs obtained from the immunized mice and exposed to $M t b$, were pooled and single cell suspension was prepared by gently pressing through frosted slides. Lungs were perfused with chilled PBS and small pieces 
were prepared and digested with collagenase $(2 \mathrm{mg} /$ $\mathrm{ml}$ ) for $30 \mathrm{~min} / 37^{\circ} \mathrm{C}$. Later, cells were passed through a sieve $(70 \mu \mathrm{M})$. Viability was checked by trypan blue dyeexclusion method and cells $\left(2 \times 10^{5} /\right.$ well $)$ were added to 96 well U-bottom culture plates and cultured with L91 (1 nmol), Pam2Cys $(50 \mathrm{ng} / \mathrm{ml})$, ST-CF $(25 \mu \mathrm{g} / \mathrm{ml})$ and medium for $72 \mathrm{~h}$.

\section{Proliferation assays}

The cells $\left(2 \times 10^{7}\right.$ cells $)$ were incubated with carboxyfluoresceinsuccinimidyl ester (CFSE) dye in PBS $(1 \mu \mathrm{M}$, $4 \mathrm{ml}$ ) at $37{ }^{\circ} \mathrm{C}$. Free CFSE was quenched with $2 \mathrm{ml}$ of FCS and excess was removed by washing with RPMIFCS-10\%. CFSE-labeled cells were cultured with either L91 $(1 \mathrm{nmol})$, Pam2Cys $(50 \mathrm{ng} / \mathrm{ml})$, ST-CF $(25 \mu \mathrm{g} / \mathrm{ml})$ or medium for $72 \mathrm{~h}$. The proliferation of CFSE-labeled cells was analyzed by flow cytometry.

\section{Intracellular cytokine and surface staining}

The cells were stimulated as mentioned in the proliferation assay and then stimulated with PMA (50 ng/ $\mathrm{ml})$ and ionomycin $(10 \mu \mathrm{M})$ for $4 \mathrm{~h}$ followed by incubation with brefeldin A $(5 \mathrm{mg} / \mathrm{ml})$ for an additional $2 \mathrm{~h}$. The cells were then harvested, washed twice with buffer (PBS-FCS-2\%) and fixed with paraformaldehyde (1X) at $4{ }^{\circ} \mathrm{C}$ for $30 \mathrm{~min}$. Fixed cells were perforated with saponin $(0.2 \%)$ and incubated with fluorochrome tagged antiIFN- $\gamma$, IL-17A and TNF- $\alpha$ Abs at $4{ }^{\circ} \mathrm{C}$ for $90 \mathrm{~min}$. The cells were washed with saponin $(0.2 \%)$, followed by wash buffer. For surface staining, the cells were incubated with either fluorochrome labeled Abs or biotinylated Abs/ streptavidin-fluorochrome conjugates. Standard protocols of washing/incubation were followed at each stage.

\section{Flow cytometry}

Flow cytometry was carried out using a FACS-Aria III and data was analyzed using the BD FACS DIVA software package (BD Biosciences, San Jose, CA). The gating strategies for FoxP3, PD-1, Tim-3, IFN- $\gamma /$ TNF- $\alpha$, IFN- $\gamma /$ IL-17, CD62L/CD44, CD127 (Additional file 1: Figure S1) and CCR6/CXCR3 expression on IL-17/IFN- $\gamma$ double positive cells (Additional file 2: Figure S2) have been shown in their respective figures.

\section{Cytokine estimation}

The cultures were set as mentioned in $\mathrm{T}$ cell proliferation assay. Later, culture supernatants (SNs) were collected and cytokine concentrations were determined using a standard sandwich ELISA [14].

\section{Culture of dendritic cells}

Monocytes were isolated from the femurs and tibia of the mice. The cells $\left(2 \times 10^{6} /\right.$ well $)$ were cultured in the presence of granulocyte macrophage colony-stimulating factor (GM-CSF; $2 \mathrm{ng} / \mathrm{ml}$ ) and interleukin-4 (IL-4; $4 \mathrm{ng}$ / $\mathrm{ml}$ ) for the generation of DCs. On day 3, the cultures were replenished with fresh medium and supplemented with GM-CSF and IL-4. On day 6, the cells were harvested, washed and added to 24 well plates $\left(2 \times 10^{5}\right.$ cells/ well). Bone marrow derived dendritic cells (BMDCs) were stimulated with either L91 ( $3 \mathrm{nmol})$, F91 ( $3 \mathrm{nmol})$, Pam2Cys $(50 \mathrm{ng} / \mathrm{ml})$ or LPS $(4 \mu \mathrm{g} / \mathrm{ml})$ for $16 \mathrm{~h}$. SNs were collected for cytokines estimation by ELISA and the expression of surface markers was assessed by flow cytometry.

\section{Western blotting for iNOS}

As mentioned above for the cultures of DCs and macrophages, BMDCs were stimulated with L91, F91, Pam2 Cys and LPS for $16 \mathrm{~h}$ in 12 well plate $\left(10^{6}\right.$ cells/well). The cells were harvested and lysed in radioimmunoprecipitation assay buffer (RIPA) containing a protease inhibitor cocktail. Protein was estimated and equal amounts $(30 \mu \mathrm{g})$ were subjected to SDS-PAGE (10\%) followed by transfer to PVDF membrane. The non-specific sites were blocked with BSA (5\%) and the blot was probed with anti-iNOS Abs (1:200) (Ab3523) or actin as a control. Later, the blot was probed with anti-rabbit-HRP Ab and finally developed using an enhanced chemiluminescence method (Lumigen, Inc. Southfield, MI). The blot was finally scanned using Image Quant LAS 4000 (GE Healthcare, Pittsburgh, PA).

\section{Demonstration of NF-KB by EMSA}

BMDCs were stimulated with L91 $(9 \mathrm{nmol}), \mathrm{F} 91(9 \mathrm{nmol})$, Pam2Cys $(150 \mathrm{ng} / \mathrm{ml})$ or LPS $(4 \mu \mathrm{g} / \mathrm{ml})$ for $30 \mathrm{~min}$ in 12 well plates $\left(10^{6}\right.$ cells/well $)$. The cells were harvested and nuclear extract was prepared. Nuclear extracts of each sample were incubated with $\left[\mathrm{P}^{32}\right]$ labeled oligonucleotides containing the binding site for NF- $\mathrm{KB}$ at $37{ }^{\circ} \mathrm{C}$ for $20 \mathrm{~min}$ to allow the formation of DNA-protein complexes, which was then resolved by native gel electrophoresis using a $6 \%$ gel. Later, the gel was dried and exposed to a blank screen at room temperature for $6-10 \mathrm{~h}$ and scanned by a phosphorimager (Fujifilm, Tokyo, Japan).

\section{Isolation and culture of human PBMCs}

Blood was obtained from BCG vaccinated healthy volunteers in sterile vacutainers. Blood was diluted with PBS in 1:1 ratio and overlaid on histopaque. Peripheral blood mononuclear cells (PBMCs) were separated by centrifugation at $400 \mathrm{~g}$ for $30 \mathrm{~min}$ at $25^{\circ} \mathrm{C}$. PBMCs were washed 3 times with PBS $+2 \%$ FCS and in vitro cultured with L91 $(1 \mathrm{nmol})$, F91 $(1 \mathrm{nmol})$ or Pam2Cys (50 ng/ml) for $96 \mathrm{~h}$. During culture, IL-2 (100U) was added after $24 \mathrm{~h}$. 


\section{Statistical analysis}

The data are presented as mean \pm standard error. Statistical analysis was performed using Graph Pad Prism employing an unpaired Student's 't'test.

\section{Results}

\section{L91 administration limits the generation of regulatory $\mathrm{T}$} cells

One of the main reasons associated with BCG failure is the generation of regulatory $\mathrm{T}$ cells (Tregs) following vaccination, which hampers its protective efficacy [5]. Consequently, we examined ex vivo generation of regulatory T cells (Tregs) in the cells isolated from the lungs of the immunized mice after 90 days of $M t b$ infection. We observed significantly ( $p \leq 0.005)$ higher percentage of FoxP3 ${ }^{+}$CD4 Tregs from the BCG vaccinated mice, as compared to the control (placebo) group (Fig. 1a, b). On the other hand, a significant reduction of the FoxP3 ${ }^{+} \mathrm{CD} 4$ Tregs $(p \leq 0.0001)$ was observed in the group of mice that was primed with BCG followed boosting with L91 (BCGL91), as compared to BCG. Thus, indicating that L91 boosting restricted BCG-mediated induction of Tregs and thereby may be augmenting immunity against $M t b$.

\section{L91 rescues CD4 T cells from exhaustion}

Mycobacterium tuberculosis is known to induce exhaustion of T cells [11]. Recently, we have demonstrated that signaling via TLR-2 rescues CD4 $\mathrm{T}$ cells from exhaustion
[11]. L91 comprises of TLR-2 agonist Pam2Cys and a MHC-II binding promiscuous peptide of Acr1 [10]. Therefore, we monitored whether BCG-L91 vaccination could rescue $\mathrm{CD} 4 \mathrm{~T}$ cells from exhaustion against $M t b$ infection. The results showed a substantial reduction of the exhaustion markers PD-1 $(p \leq 0.05)$ (Fig. 1c, d) and Tim-3 ( $p \leq 0.05)$ (Fig. 1e, f) on the CD4 gated T cells obtained from BCG-L91 group, compared to those of BCG group (Fig. 1c-f). There was no difference in the expression of these two markers on the cells isolated from BCG and the placebo group. These results demonstrate that L91-boosting prevented $\mathrm{T}$ cell exhaustion in $M t b$ infected mice.

\section{BCG-L91 elicits predominantly Th1 and Th17 immunity}

Th1 cells and Th17 cells are two major arms of adaptive immunity that play a cardinal role in safeguarding against $M t b$ [15]. Th1 cells are known to mediate protection against $M t b$ through the release of IFN- $\gamma$ and TNF- $\alpha$ $[7,10,16]$. Th17 cells confer protection by chemokine mediated recruitment of the cells of innate and adaptive immunity $[17,18]$. BCG has shown to elicit a mixed Th1 and Th2 response and also a weak Th17 response $[19,20]$. Our results show that L91 booster significantly augmented Th1 and Th17 immunity, as evidenced by a greater release of IFN- $\gamma$ following in vitro stimulation with L91 $(p \leq 0.005)$ or ST-CF $(p \leq 0.05)$ and IL-17A (in vitro stimulation with L91: $p \leq 0.005$; ST-CF: $p \leq 0.0005)$

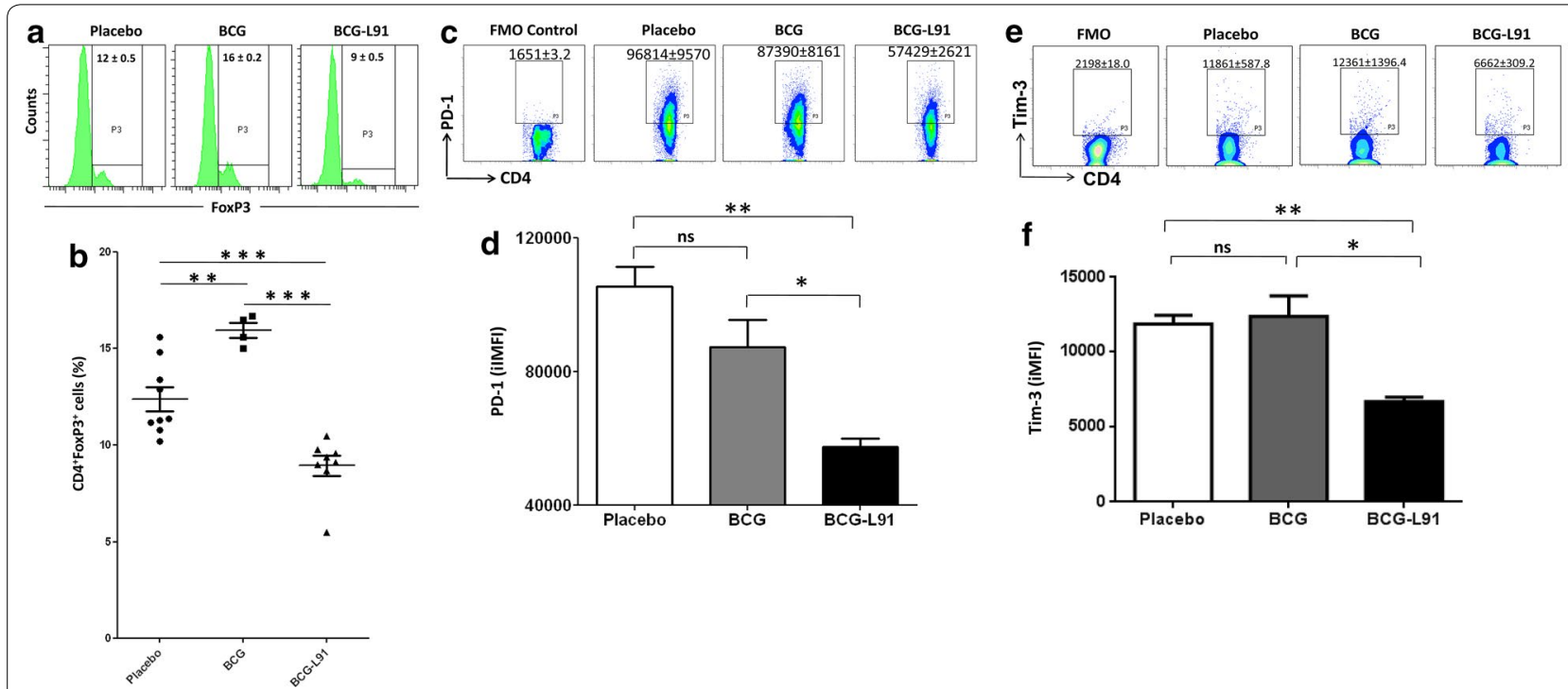

Fig. 1 BCG-L91 limits the generation of Tregs and rescues CD4T cells from exhaustion. The mice primed and boosted with BCG-L91 and infected with Mtb were sacrificed. The control animals were immunized with either BCG or placebo. A single cell suspension was prepared from lungs and ex vivo examined for the expression of a FoxP3; c PD-1; e Tim-3 by flow cytometry. b Scatter dot plot depicts percent population of FoxP3 ${ }^{+}$CD4 $T$ cells. The figures (Mean \pm SE) in the inset the percentage of positive cells. Each dot in the scatter plot signifies one mouse. The bar diagrams correspond to the iMFI for d PD-1; f Tim-3. Data are pooled from 2 independent experiments and shown as Mean \pm SEM. ${ }^{*} p \leq 0.05,{ }^{* *} p \leq 0.005$, ${ }^{* * *} p \leq 0.0001$, ns not significant 
by lung cells (Fig. 2a, b) than the control groups. Thus, BCG-primed and antigen-boost strategy generated better immunity than BCG alone against $M t b[17,21]$.

\section{Induction of multifunctional Th1 cells and Th17 cells by BCG-L91}

Polyfunctional Th1 cells and Th17 cells are considered better in protecting against $M t b$, compared to their counter parts secreting single cytokine [22, 23]. In our study here, the cells isolated from the lungs of the BCG-L91 group showed significantly greater expansion in the percentage of multifunctional Th1 cells $\left(\mathrm{IFN}-\gamma^{+} \mathrm{TNF}-\alpha^{+}\right)$ (L91: $p \leq 0.005$, ST-CF: $p \leq 0.005$ ) and Th17 cells $\left(\mathrm{IL}-17^{+} \mathrm{IFN}^{+} \gamma^{+}\right)(\mathrm{L} 91: p \leq 0.005$, ST-CF: $p \leq 0.05)$ following in vitro stimulation with either L91 or ST-CF, compared to the BCG group (Fig. 2c-f).

\section{Multifunctional Th 17 cells express $\mathrm{CCR} 6^{\text {hi }} \mathrm{CXCR} 3^{\text {hi }}$ phenotype}

Multifunctional Th17 cells (IFN- $\gamma^{+} \mathrm{IL}^{-17 \mathrm{~A}^{+}}$) co-expressing CXCR3/CCR6 are known to upregulate the ligands for CXCR3 (CXCL9/CXCL10/CXCL11) on the lung parenchymal cells, which helps to recruit Th1 cells to the site of infection $[17,18]$. The results of our study showed that significantly more $\mathrm{CXCR}^{+}{ }^{+} \mathrm{CCR} 6^{+}$co-expressing polyfunctional Th17 cells $\left(\mathrm{IFN}-\gamma^{+} \mathrm{IL}-17 \mathrm{~A}^{+}\right)$had been observed in the lungs of the BCG-L91 group following culturing with L91 $(p \leq 0.0005)$ and ST-CF $(p \leq 0.05)$ (Fig. 2g, h).

\section{BCG-L91 enhances the frequency of T cell memory response}

One of the main reasons for BCG's inability to evoke long-term protection against $M t b$ is its failure to generate enduring memory $\mathrm{T}$ cells $[5,10]$. The results of this study show that L91 induced significantly greater expansion in the pool of both central $\left(\mathrm{CD} 44^{\mathrm{hi}} \mathrm{CD} 62 \mathrm{~L}^{\mathrm{hi}}\right.$; L91: $p \leq 0.05$; ST-CF: $p \leq 0.005)$ and effector memory (CD44 ${ }^{\text {hi }} \mathrm{CD} 62 \mathrm{~L}^{\text {lo }}$; L91: $p \leq 0.05$; ST-CF: $p \leq 0.05)$ CD4 T cells in the BCGL91 administered mice than the control group following in vivo stimulation of L91 and ST-CF (Fig. 3a-c). These results were further substantiated by significantly $(p \leq 0.005)$ higher display of CD127, another marker for memory CD4 T cells (Fig. 3d, e). No discernible change was detected in the case of BCG group. The CD127 has been established to be an important marker for the sustenance of memory CD4 $\mathrm{T}$ cells [24].

\section{L91 reduces the suppression of antigen presenting cells by enhancing NF-KB and iNOS expression}

The Acr 1 antigen of $M t b$ is known to tolerize dendritic cells by upregulating the inhibitory molecule Tim- 3 and

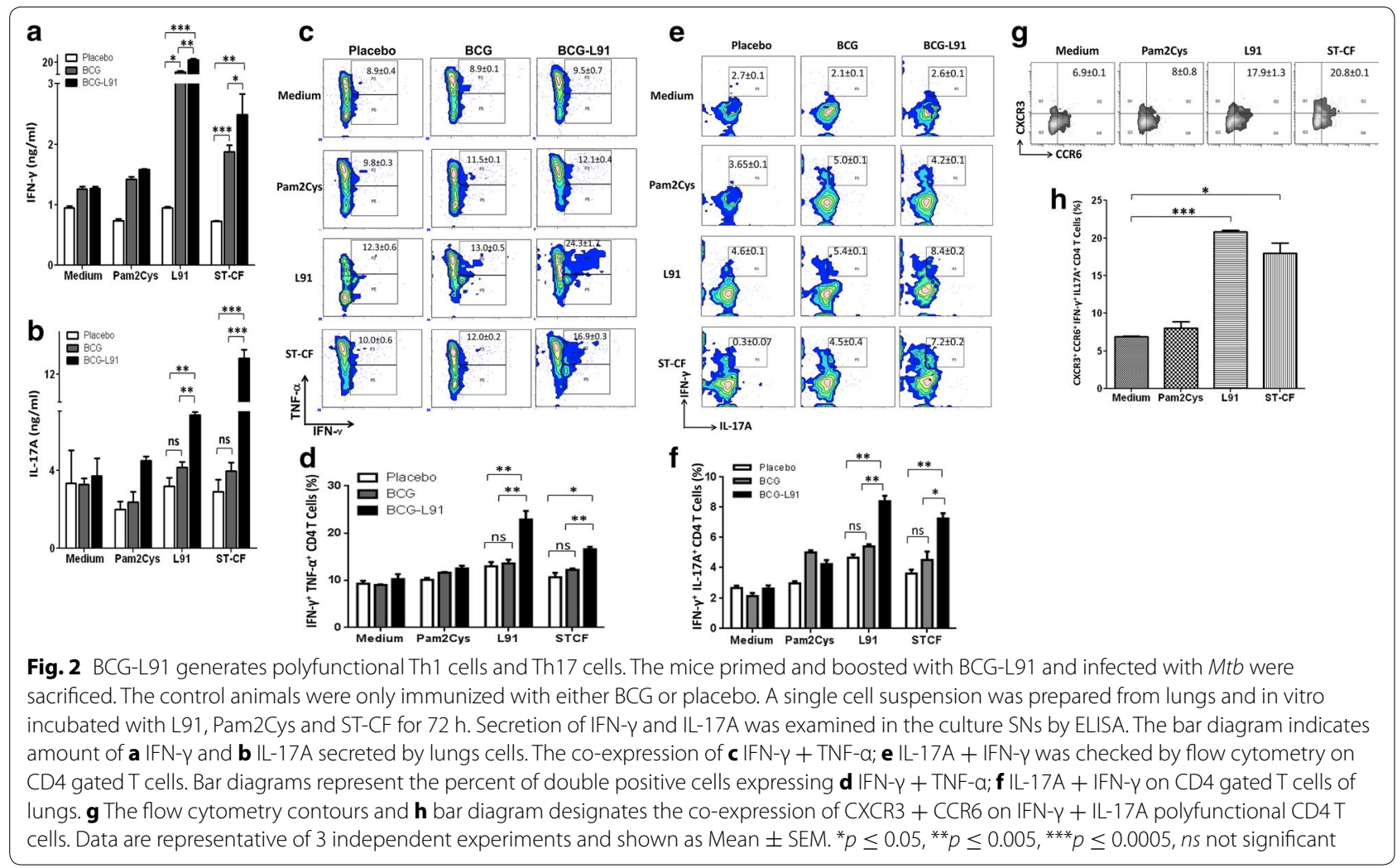




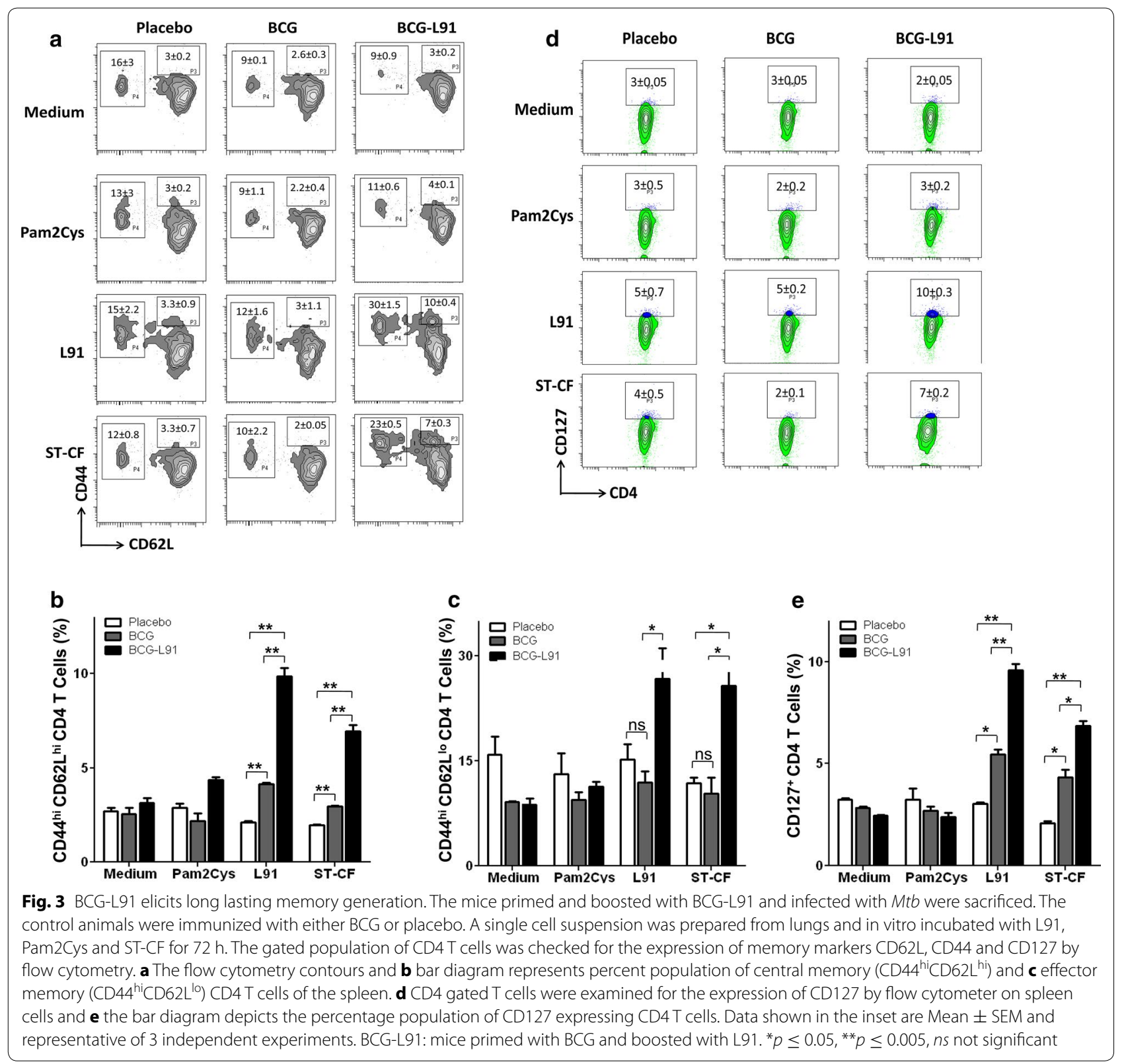

consequently suppresses the host immunity [25]. L91 is derived from Acr1. Hence, it was worth to examine the influence of L91 on Tim-3 expression on dendritic cells. Our results show that in vitro stimulation with L91 significantly ( $p \leq 0.0005$ ) downregulated the expression of Tim-3 compared to unstimulated cultures (Fig. 4a). L91 comprises of the components that are capable of inducing both innate and adaptive immunity [10]. Innate immunity is the first line of defense to combat against any pathogen [26]. Nitric oxide (NO) mediated killing of $M t b$ is one of the well-established protection mechanism [27]. Hence, we thought it would be worth to check the impact of L91 on DCs in inducing the release of NO. Interestingly, we observed a dose-dependent increase in iNOS, the enzyme responsible for NO synthesis (Fig. 4b) upon stimulation with L91. Additionally, L91 considerably ( $p \leq 0.0005)$ augmented TNF- $\alpha$ secretion (Fig. 4c). TNF- $\alpha$ is a major factor in restricting the intracellular survival of $M t b[7,25]$. Further, the augmentation in the expression of NF- $\mathrm{kB}$ was also detected with L91 stimulation (Fig. 4d). NF- $k B$ is a key transcription factor responsible for the propagation of cells and pro-inflammatory responses [28]. Besides L91, considerably higher NF- $\mathrm{kB}$ expression was detected following stimulation with the Pam2Cys control but not un-lipidated peptide (F91). These results together demonstrate 

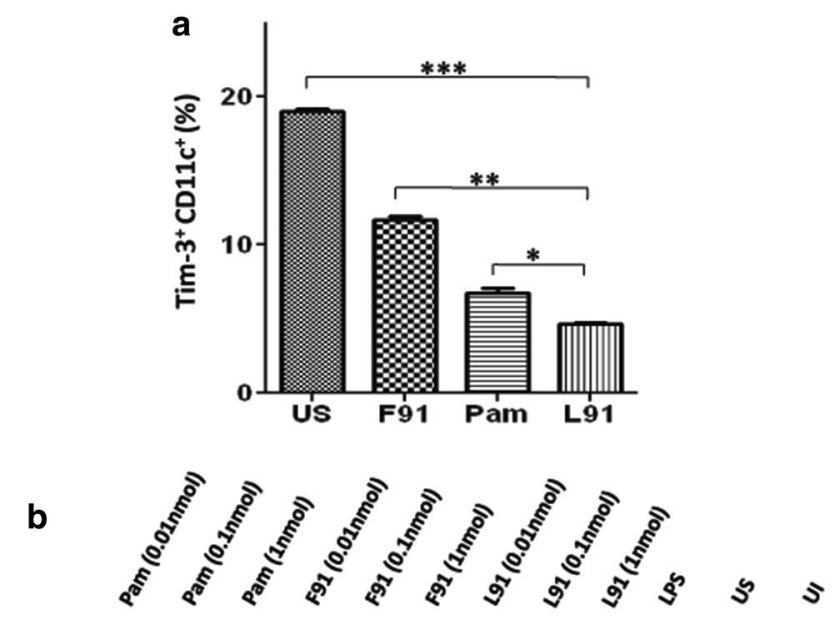

iNOS

ACTIN

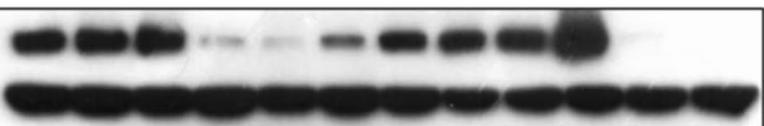

Fig. 4 L91 suppresses Tim-3 and induces iNOS and NF-KB on DCs. Bone marrow derived DCs were stimulated with L91, F91, Pam2Cys and LPS. The expression of Tim-3 on CD11c gated population was checked by flow cytometry. a Bar diagram indicates percent of Tim- $3^{+}$population on CD11 $\mathrm{C}^{+}$ DCs. b The expression of iNOS was monitored by Western blotting. c The secretion of TNF-a was measured in the culture SNs of DCs by ELISA. d The expression of NF-KB was examined by EMSA. FB free probe, US unstimulated cells, Pam Pam2Cys, F91 non-lipidated peptide, L91 lipidated peptide, F91 non-lipidated, Pam Pam2Cys, LPS lipopolysaccharides. Data shown are representative of 2 comparable experiments and correspond to Mean \pm SEM. ${ }^{*} p \leq 0.05,{ }^{* *} p \leq 0.005,{ }^{* * *} p \leq 0.0005$, ns not significant

the role of Pam2Cys as a component of L91 in promoting the release of molecules of innate immunity responsible for protection.

\section{L91 boosting enhances protective efficacy of BCG vaccine}

After establishing the role of L91 in inducing the longlasting memory $\mathrm{T}$ cell response, we next evaluated the protective efficacy of BCG-L91 against $M t b$. To generate bona fide memory $\mathrm{T}$ cell response, BCG-L91 vaccinated mice were aerosol challenged with $M t b 90$ days after the last immunization. Bacterial burden in the lungs and spleen was enumerated 90 days following the challenge. The results show that $\mathrm{L} 91$ boosting led to a greater reduction in the mycobacterial burden in the lungs $(p \leq 0.005)$ and spleen $(p \leq 0.005)$, compared to BCG-vaccinated group, and also the Pam2Cys and placebo control (Fig. 5a, b). The decrease in the CFU in the spleen also signifies the importance of BCG-L91 in restricting the dissemination of $M t b$.

Further, we substantiated CFU data by histopathological study of lungs. Animals immunized with BCG-L91 exhibited reduced pathology in the lungs, manifested by decreased macrophage infiltration and lesser and smaller size of granulomas, fewer scattered peribronchiolar lymphocyte-rich areas and better preserved alveolar spaces, when compared to the BCG group, placebo and Pam2Cys controls. The control animals revealed
$M t b$ induced severe pathology that was characterized by the larger size and number of lymphocyte rich compact granulomas with signs of irregular lung architecture due to excessive inflammation. Peribronchiolar cuffs and bigger confluent areas of consolidated mixed lymphocyteshistiocytes were also apparent (Fig. 5c). The quantitative assessment of the granulomas in lung sections revealed a decreased $M t b$ burden in BCG-L91 immunized animals (Fig. 5d).

\section{L91 augments the expansion and activation of human CD4 T cells}

L91 efficiently amplified BCG induced immunity in the experimental model of TB. Hence, we were next curious to know whether L91 was able to activate human CD4 T cells obtained from BCG vaccinated healthy volunteers. PBMCs cultured with L91 exhibited significantly higher $(p \leq 0.0005)$ proliferation and upregulation of the activation marker CD25 ( $p \leq 0.0005)$ on CD4 T cells, as compared to those cultured with free peptide or Pam2Cys control (Fig. 6a-c).

\section{L91 enhances the generation of enduring polyfunctional Th1 cells and Th 17 cells in human PBMC}

We next observed that L91 stimulation improved the generation of Th1 cells, as it significantly $(p \leq 0.05)$ expanded the percentage of IFN- $\gamma^{+} \mathrm{CD} 4 \mathrm{~T}$ cells. Further, 

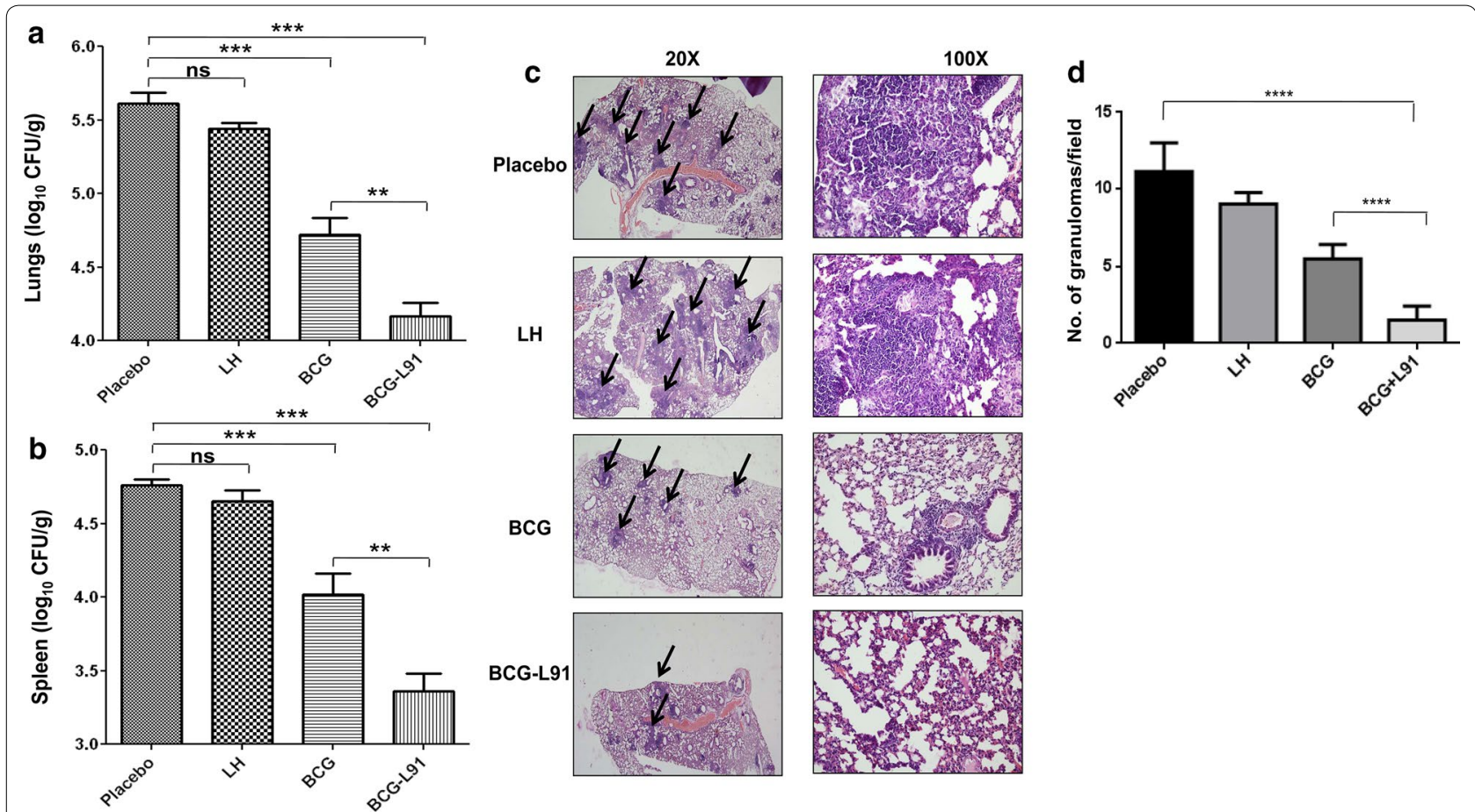

Fig. 5 Prime boosting with BCG-L91 improves the protective efficacy of BCG. Animals were vaccinated with BCG and later boosted twice with L91. Ninety days of last booster, the mice were aerosol challenged with Mtb. After 90 days, bacterial burden was enumerated in the $\mathbf{a}$ lungs and $\mathbf{b}$ spleen. Control animals received saline, LH and BCG. The bacterial number is expressed as $\log _{10} \mathrm{CFU} / \mathrm{g}$ of tissue. Results shown as bar diagram are Mean \pm SEM and pooled data from 3 experiments ( $n=3$ mice/group). $\mathbf{c}$ Histopathological analysis of lung was done after staining the sections with hematoxylin and eosin. The magnification is depicted at $20 \times / 100 \times$ for lungs. The arrows indicate granulomas or tubercle. The asterisk represents the level of significance. $\mathbf{d}$ The quantitative assessment of the Mtb infected lungs was done by counting the granulomas in ten random fields of the gross histopathological sections and the average is expressed as Mean \pm SD. LH lipidated hemagglutinin peptide, BCG-L91 mice primed with BCG and boosted with L91. ${ }^{* *} p \leq 0.005,{ }^{* * *} p \leq 0.0005$, ns not significant

we observed increased frequency $(p \leq 0.005)$ of polyfunctional Th1 cells expressing both IFN- $\gamma$ and TNF- $\alpha$ (Fig. 7a-d). The results were obtained using blood from the non-TB endemic Australian population. Furthermore, we also monitored the efficacy of L91 using PBMCs from BCG-vaccinated healthy volunteers of the TB-endemic Indian population. It is worth to mention here that the BCG has failed to protect Indian population from $M t b$ [4]. We observed a significant augmentation in Th1 and Th17 immunity, as documented by the increased percentage of IFN- $\gamma^{+}(p \leq 0.0005)$ and IL-17A $^{+}$ $(p \leq 0.005) \mathrm{CD} 4 \mathrm{~T}$ cells, respectively (Fig. 8a-c). Further, enhanced frequency $(p \leq 0.005)$ of IFN- $\gamma^{+}$and IL-17A ${ }^{+}$ polyfunctional Th17 cells was detected (Fig. 8d). Furthermore, expansion $(p \leq 0.005)$ of the pool of the memory precursors of $\mathrm{CD} 4 \mathrm{~T}$ cells $\left(\mathrm{CD} 45 \mathrm{RA}^{+} \mathrm{CD} 45 \mathrm{RO}^{+}\right)$was noted (Fig. 8e). These results suggest that $\mathrm{L} 91$ efficiently activated polyfunctional human Th1 cells and Th17 cells and expanded the pool of memory CD4 T cells. Thus, has a great potential to reinvigorate the efficacy of BCG vaccine in TB endemic and non-endemic population.

\section{Discussion}

The slow progress of the 'Stop TB Program' and the emergence of drug resistant strains of $M t b$ poses an urgent challenge for the scientific community to develop an effective vaccine against $M t b$. BCG is the only currently available vaccine, which is widely administered worldwide [10]. Nevertheless, TB accounts for 9.6 million new cases and 1.5 million mortality annually [1]. In many ways BCG is a controversial vaccine, since it protects $80 \%$ of individuals in non-TB endemic regions and $0 \%$ in TB-endemic zones [7, 29]. BCG protects children but not adults living in TB-endemic regions, further demonstrating its variable efficacy $[5,10,30]$. Many approaches to improve BCG vaccine have been tried, which includes recombinant BCG with different antigenic formulations [29-31]. However, the introduction of a globally effective vaccine candidate, at least in TB-endemic zones, is yet to be achieved. The high protective efficacy of BCG in the developed world and children of TB-endemic sectors suggest that $\mathrm{BCG}$ has the adequate antigenic repertoire to protect against $M t b$ [23]. Nevertheless, BCG efficacy 


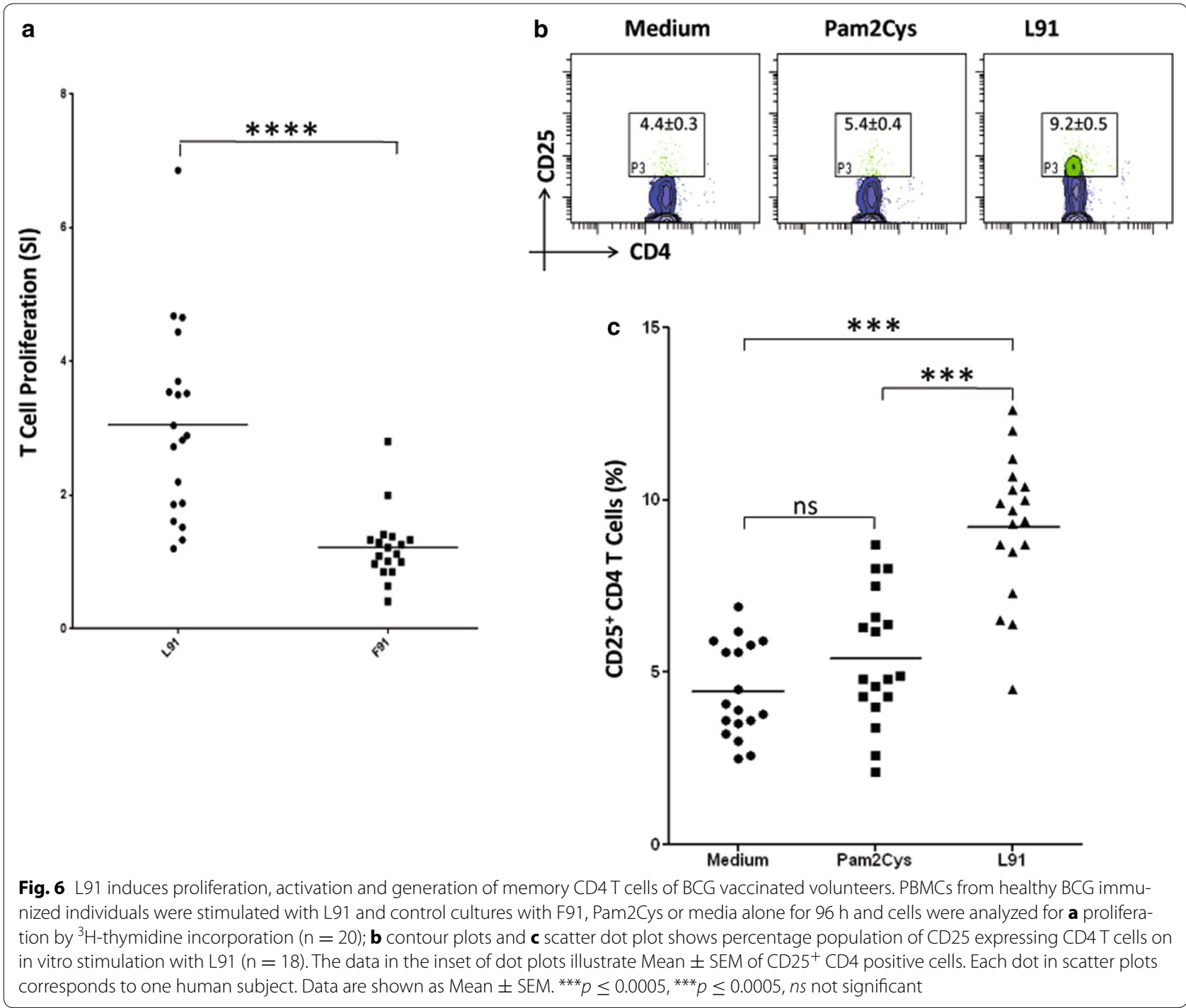

wanes with age, which indicates its failure to elicit lifelong immunity [32]. In this context, several approaches are being tried to boost BCG ability to generate enduring memory $\mathrm{T}$ cells and protection against TB $[8,9]$.

L91 is a chimeric peptide comprising of MHC-II binding peptide and Pam2Cys and promotes the generation of long-term memory CD4 T cells [10]. Therefore, we were encouraged to test the potential of L91 to bolster BCG efficacy by promoting the persistence of memory CD4 $\mathrm{T}$ cells and consequently long lasting protection against Mtb.

We carried out a study in which L91 was used to boost the immune response primed by BCG vaccination. As compared to BCG group, the following major findings have been obtained: (i) significant reduction in the number of CFU in the lungs and diminished pathological changes in the $M t b$ infected mice; (ii) higher proliferation of the CD4 T cells and upregulated expression of IFN- $\gamma$ and IL-17A; (iii) robust increase in the pool of multifunctional Th1 cells $\left(\mathrm{IFN}-\gamma^{+} / \mathrm{TNF}-\alpha^{+}\right)$and Th17 cells (IL-17 ${ }^{+} /$ IFN $-\gamma^{+} / \mathrm{CXCR}^{+} / \mathrm{CCR}^{+}{ }^{+}$); (iv) expansion in the percentage of central and effector memory CD4 $\mathrm{T}$ cells; (v) the mechanism involved in the reduction of bacterial burden was through iNOS and TNF- $\alpha$; (vi) the PBMCs obtained from the BCG vaccinated volunteers showed increase in the frequency of polyfunctional Th1 cells, Th17 cells and memory CD4 T cells on in vitro exposure to L91.

One of the main reasons associated with the weak efficacy of BCG vaccine to protect against $M t b$ is attributed to the generation of Tregs following immunization, which dampens Th1 immunity through release of IL-10 [33-35]. The decrease in the frequency of Tregs in the 

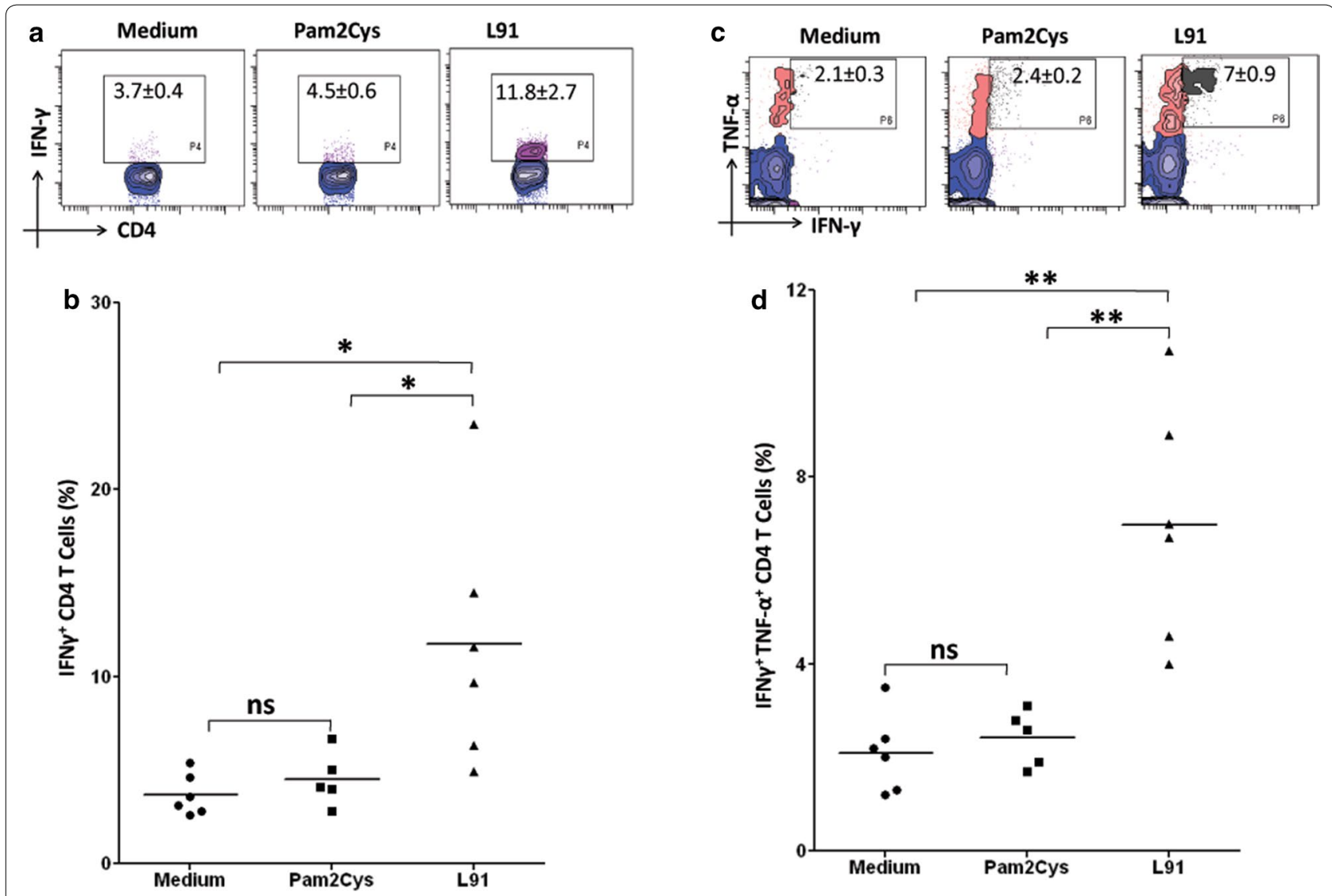

Fig. 7 L91 elicits polyfunctional Th1 cells in BCG vaccinated human subjects of the non-TB endemic population. Human PBMCs obtained from BCG-vaccinated individuals from non-TB endemic population were analyzed by flow cytometry for the expression of $\mathbf{a}$ IFN- $\gamma$ and $\mathbf{b}$ represented by dot plots and (c, d) IFN- $\gamma$ and TNF-a together. Each dot corresponds to one human subject. Data are shown as Mean \pm SEM. ${ }^{*} p \leq 0.05$, ${ }^{* *} p \leq 0.005$, ns not significant

BCG-L91 group compared to BCG group clearly indicates the importance of L91 boosting in reducing the number of Tregs. The inhibition in the development of Tregs by BCG-L91 may be due to the augmented secretion of IFN- $\gamma$ by Th1 cells $[36,37]$. Furthermore, the signaling events stimulated by TGF- $\beta$ are negatively regulated by IFN- $\gamma$ [38]. TGF- $\beta$ is responsible for the differentiation of naïve CD4 T cells to Tregs. IFN- $\gamma$-mediated phosphorylation of STAT1 leads to the expression of T-bet and Smad7 [38, 39], which is known to suppress the regulatory function of Tregs [40].

It has also been well documented that $M t b$ drives Th1 cells to exhaustion [11]. Th1 cells play a crucial role in protecting against $M t b[10,11]$. Recently, we have demonstrated that triggering of TLR-2 with Pam2Cys can enhance the generation of memory Th1 cells and rescues them from exhaustion by downregulating PD-1 and Tim-3 and amplifying co-stimulatory signals and the secretion of pro-inflammatory cytokines [10, 11]. TLR-2 agonist Pam2 Cys is a major component of L91. TLR-2 signaling not only rescues $\mathrm{T}$ cells from exhaustion but also stimulates both innate and adaptive immunity. Further, the higher susceptibility of TLR-2 $2^{-1-}$ animals to $M t b$ indicates an important role of TLR-2 in protection [41, 42].

The induction of Th1 immunity plays a fundamental role in protecting against intracellular pathogens such as $M t b[7,8,10]$. Further, MyD88 $8^{-/-}$animals with partially compromised Th1 immunity are more susceptible to TB [15]. We demonstrated that the L91 booster substantially augmented Th1 immunity, as evidenced by improvement in IFN- $\gamma$ secretion. Pam2Cys is known to stimulate DCs to release IL-12 through TLR-2 signaling [10]. IL-12 is a differentiating factor for Th1 cells. Thus, L91 preferentially expands Th1 cells. Furthermore, we noted the generation of Th17 cells in the animals vaccinated with BCG-L91. Recently, it was demonstrated that Th17 cells confer protection against $M t b$ by recruiting Th1 cells to the site of infection. Th17 cells show a robust effect on chemokine-mediated infiltration of macrophages and neutrophils at the site of infection $[17,18]$.

It has been shown that the protective role of polyfunctional Th1 cells $\left(\mathrm{IFN}-\gamma^{+} / \mathrm{TNF}-\alpha^{+}\right)$and Th17 cells 

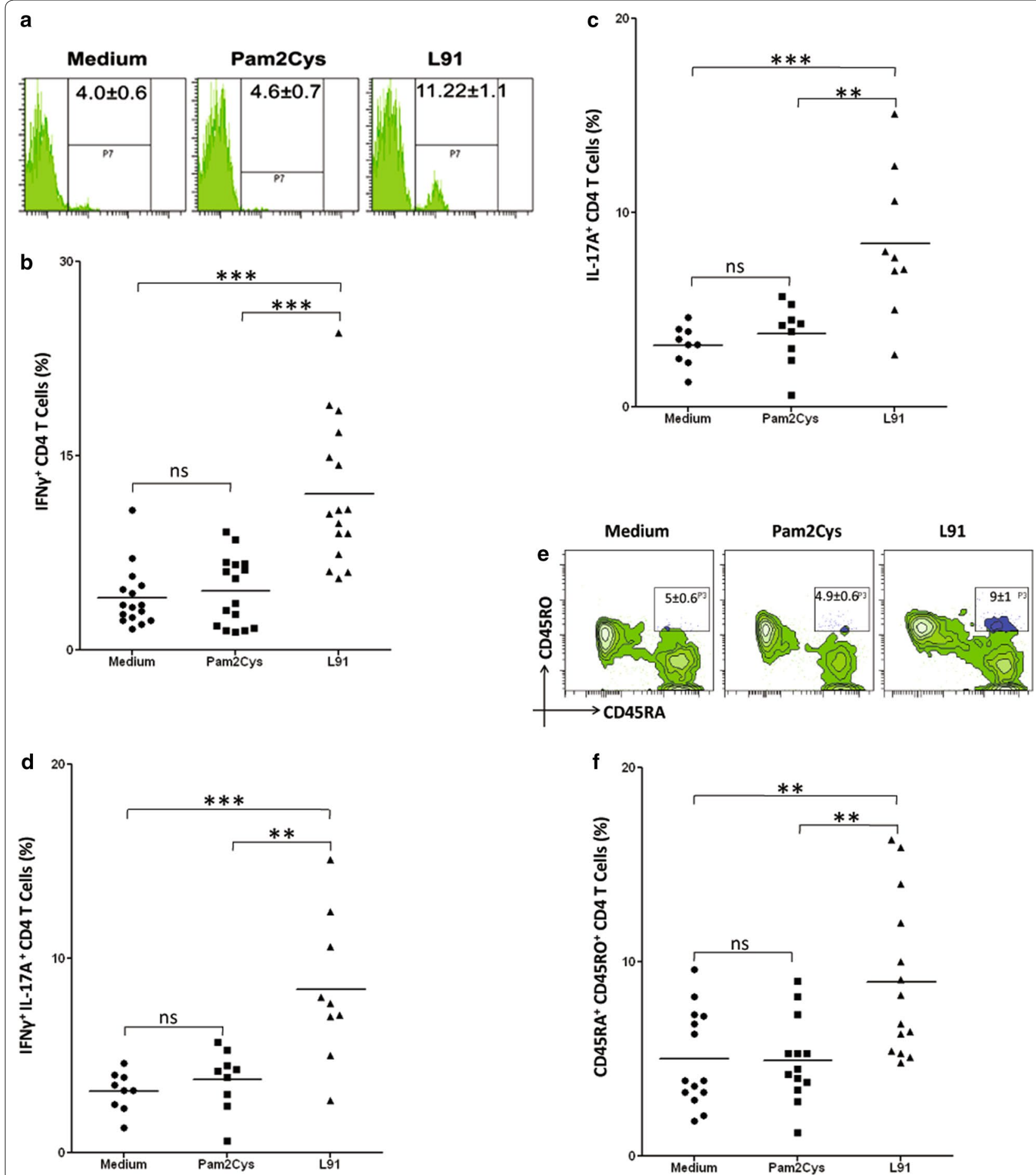

Fig. 8 L91 elicits long lasting Th1 and Th17 immune response of BCG vaccinated volunteers. PBMCs of BCG vaccinated human subjects were stimulated with L91 and control cultures with Pam2Cys and medium for $96 \mathrm{~h}$ and analyzed for the expression of memory markers and cytokines by flow cytometer. a Histogram and $\mathbf{b}$ scatter plot depicts percent population CD4T cell expressing IFN- $\gamma(n=16)$. Likewise, c scatter dot plot represents percent population of CD4T cell expressing IL-17A $(n=9)$. d Polyfunctional T cells were identified on CD4 gated T cells co-expressing IFN- $\gamma$ and IL-17A $(n=9)$. e Histogram and $\mathbf{f}$ scatter dot plot represent the percentage of CD45RA ${ }^{+}$CD45RO ${ }^{+}$memory CD4 T cells in BCG immunized human subjects $(n=14)$. Data are shown as Mean \pm SEM. ${ }^{* *} p \leq 0.005,{ }^{* * *} p \leq 0.0005, n s$ not significant 
$\left(\mathrm{IFN}-\gamma^{+} / \mathrm{IL}-17 \mathrm{~A}^{+}\right)$is qualitatively superior to their single cytokine secreting counterparts, since they can effectively restrict the survival of $M t b[10,17]$. Interestingly, we found that BCG-L91 immunization expanded IFN- $\gamma$ and TNF- $\alpha$ secreting polyfunctional Th1 cells. IFN $-\gamma$ is known to activate macrophages and increase their bactericidal effect and TNF- $\alpha$ restricts the growth of $M t b[43$, 44]. Such Th17 cells are reported to have a better protective capacity than single cytokine secreting cells [17, 18, 45]. Further, Th17 cells expressing CXCR $3^{+} \mathrm{CCR}^{+}$ are associated with protection against $M t b$, while those displaying $\mathrm{CCR}^{+}{ }^{+} \mathrm{CCR}_{4}{ }^{+}$are involved in autoimmunity $[17,45]$. We found in this study that L91 preferentially expanded polyfunctional Th17 cells displaying CXCR3 and CCR6. Consequently, suggesting non-pathogenic nature of Th17 cells.

The importance of NO has been well documented in the killing of $M t b$ by inducing apoptosis of infected cells [27]. L91 activates DCs and augments the expression of iNOS and TNF- $\alpha$. Both NO and TNF- $\alpha$ cumulatively protect the host from $M t b$ and the mechanism deciphered is by inducing apoptosis of $M t b$-infected cells. Apoptosis releases intracellular bacteria, which provides an opportunity for the activated macrophages to engulf and eliminate them [27]. We have shown that a booster dose of L91 efficiently bolsters the protective efficacy of BCG and significantly constrains bacterial burden in the lungs and spleen even after a lengthy period of 229 days of vaccination. The results of protection study suggest that L91 has a unique capability of generation and maintenance of long-lasting memory CD4 T cells and protection against $M t b[10]$.

Finally, we validated the efficacy of L91 employing PBMCs of BCG vaccinated healthy adult volunteers from TB-endemic and non-endemic zones. Importantly, CD4 $\mathrm{T}$ cells exhibited an enhacement in the expression of IFN- $\gamma$ and IL-17A on in vitro stimulation with L91. Furthermore, an increase in the frequency of polyfunctional Th1 cells and Th17 cells was detected. Finally, it is worth to mention here that a remarkable expansion in the pool of memory CD4 T cells was found in our study, which illustrates the role of L91 in reinvigorating BCG efficacy to evoke long-lasting immunity responsible for protection against $M t b$.

\section{Conclusions}

This study indicates that BCG priming followed by L91 boosting could efficiently overcome the low long-term protective efficacy associated with BCG vaccination by generating enduring memory $\mathrm{T}$ cells and protection against $M t b$. The possible mechanism involved is through the involvement of both innate (NO and TNF$\alpha$ ) and adaptive (long-lasting polyfunctional Th1 cells and
Th17 cells) immunity. In future, this vaccination strategy of BCG-L91 vaccine may be developed into an effective strategy to control TB in the TB-endemic population.

\section{Additional files}

\begin{abstract}
Additional file 1: Figure S1. Gating strategy for monitoring the expression of FoxP3, PD-1, Tim-3, IFN- $\gamma$, IFN- $\gamma^{+}$TNF- $a$, IL-17A, IL-17A+IFN- $\gamma$, CD62L $L^{+}$CD44 and CD127 on $\mathrm{CD}^{+} T$ cells. CD4 ${ }^{+} \mathrm{T}$ cells were stained with the fluorochrome labeled Abs to FoxP3, PD-1, Tim-3, IFN- $\gamma$, IFN- $\gamma^{+}$TNF- $a$, IL-17A, IL-17A ${ }^{+}$IFN- $\gamma$, CD62 L ${ }^{+}$CD44, CD127. The P1 gate was made on lymphocyte zone and $\mathrm{P} 2$ gate on SSC-A and CD4 ${ }^{+} \mathrm{T}$ cells. The expression of FoxP3, PD-1, Tim-3, IFN- $\gamma$, IFN- $\gamma^{+}$TNF- $a$, IL-17A, IL-17A ${ }^{+}$IFN- $\gamma$, CD62 L ${ }^{+}$CD44 and CD127 was observed on P2 gated population (CD4 ${ }^{+}$and SSC- $\left.{ }^{+}\right)$. The unstained cells failed to show any $\mathrm{CD}^{+} \mathrm{T}$ cell population.

Additional file 2: Figure S2. Gating procedure for monitoring the expression of $C X C R 3^{+} C C R 6$ on IFN- $\gamma^{+} / L-17 A$ expressing CD4 T cells. The P1 gate was made on lymphocyte zone and $\mathrm{P} 2$ gate on SSC-A and CD4 ${ }^{+} \mathrm{T}$ cells. The display of IL-17A ${ }^{+} \mathrm{IFN}-\gamma$ (P3 gate) was monitored on P2 zone (CD4 ${ }^{+}$ and $\mathrm{SSC}^{+}$). The expression of $\mathrm{CXCR}^{+}{ }^{+} \mathrm{CCR} 6$ was examined on $\mathrm{P} 3$ region (IL-17A ${ }^{+}$IFN- $\gamma$ positive cells). The unstained cells failed to show any CD4 ${ }^{+}$ T cell population.
\end{abstract}

\section{Abbreviations}

BCG: Bacillus Calmette-Guérin; Mtb: Mycobacterium tuberculosis; CD: cluster of differentiation; IFN: interferon; TNF: tumor necrosis factor; IL: interleukin; PD: programmed cell death; PBMC: peripheral blood mononuclear cell; TB: tuberculosis; TLR: toll like receptor; Acr: alpha-crystallin; PBS: phosphate buffered saline; CFU: colony forming unit; ST-CF: short term culture filtrate; CFSE: carboxyfluoresceinsuccinimidyl ester; PMA: phorbol myristate acetate; CCR/ CXCR: chemokine and cytokine receptor; GM-CSF: granulocyte-macrophage colony-stimulating factor; LPS: lipopolysaccharides; RIPA: radioimmunoprecipitation assay buffer; iNOS: nitric oxide synthases; MHC: major histocompatibility complex; NO: nitric oxide; SNs: supernatants.

\section{Authors' contributions}

Conceived and designed the experiments: PKR, JNA, DCJ. Performed the experiments: PKR, SBC, SN, WZ, SKM and SP. Analyzed the data: PKR, JNA. Contributed reagents/materials/analysis tools: WZ, AKJ and DCJ. Wrote the paper: PKR and JNA. All authors read and approved the final manuscript.

\section{Author details}

${ }^{1}$ CSIR-Institute of Microbial Technology, Chandigarh, India. ${ }^{2}$ Present Address: Department of Microbiology and Immunology, Pennsylvania State University College of Medicine, Hershey, PA 17033, USA. ${ }^{3}$ Department of Microbiology and Immunology, Peter Doherty Institute for Infection and Immunity, The University of Melbourne, Parkville, VIC 3010, Australia. ${ }^{4}$ Department of Pulmonary Medicine, Government Medical College and Hospital, Chandigarh, India.

\section{Acknowledgements}

We are thankful to Dr. B. N. Dutta, Medicos Centre, Chandigarh, India for histopathological analysis and Dr. Weshely Kujur for English editing. PKR, SBC, SKM, $\mathrm{SP}$ are recipients of CSIR-fellowship. SN is a recipient of DBT-fellowship.

\section{Competing interests}

The authors declare that they have no competing interests.

\section{Availability of data and materials}

All data needed to conclude the study is provided within this publication.

\section{Ethical statement}

All the animal related experiments were approved by the Institutional Animal Ethics Committee of the CSIR-IMTECH for project license No. IAEC 11/21 and experiments were carried out in accordance to the National Regulatory Guidelines issued by the Committee for the Purpose of Control and Supervision of Experiments on Animals (No. 55/1999/CPCSEA), Ministry of Environment and 
Forest, Government of India. All the human blood related work was approved by Institutional ethics committee government medical college and hospital, Chandigarh for project license GMC/TA-I (19D) 2010/06776 and experimental protocols were strictly conducted in accordance with the ethical guidelines for biomedical research on human subjects by Central Ethics Committee on Human Research (CECHR), ICMR-2000 and those as contained in 'Declaration of Helsinki'. All the donors provided informed consent in writing. No child was involved in this study.

\section{Funding}

This work was supported by the Department of Biotechnology, Ministry of Science and Technology, Government of India, New Delhi, India. (DBT grant GAP 103 to Javed N Agrewala). PKR, SBC, SKM, SP are recipients of CSIR fellowship. $\mathrm{SN}$ is a recipient of DBT fellowship.

\section{Publisher's Note}

Springer Nature remains neutral with regard to jurisdictional claims in published maps and institutional affiliations.

Received: 26 May 2017 Accepted: 14 September 2017 Published online: 06 October 2017

\section{References}

1. World Health Organization. Global tuberculosis report 2015. 2015.

2. Soualhine H, Deghmane AE, Sun J, Mak K, Talal A, Av-Gay Y, Hmama Z. Mycobacterium bovis Bacillus Calmette-Guerin secreting active cathepsin S stimulates expression of mature MHC class II molecules and antigen presentation in human macrophages. J Immunol. 2007;179:5137-45.

3. Matsuo K, Yasutomi Y. Mycobacterium bovis Bacille Calmette-Guerin as a vaccine vector for global infectious disease control. Tuberc Res Treat. 2011;2011:574591.

4. Narayanan PR. Influence of sex, age \& nontuberculous infection at intake on the efficacy of BCG: re-analysis of 15-year data from a double-blind randomized control trial in South India. Indian J Med Res. 2006:123:119-24.

5. Gowthaman U, Rai PK, Khan N, Jackson DC, Agrewala JN. Lipidated promiscuous peptides vaccine for tuberculosis-endemic regions. Trends Mol Med. 2012;18:607-14.

6. Andersen P. TB vaccines: progress and problems. Trends Immunol. 2001:22:160-8.

7. Singh V, Jain S, Gowthaman U, Parihar P, Gupta P, Gupta UD, Agrewala JN. Co-administration of IL-1 + IL-6 + TNF-alpha with Mycobacterium tuberculosis infected macrophages vaccine induces better protective $T$ cell memory than BCG. PLoS ONE. 2011;6:e16097.

8. Singh V, Gowthaman U, Jain S, Parihar P, Banskar S, Gupta P, Gupta UD, Agrewala JN. Coadministration of interleukins 7 and 15 with Bacille Calmette-Guerin mounts enduring T cell memory response against Mycobacterium tuberculosis. J Infect Dis. 2010;202:480-9.

9. Siddiqui KF, Amir M, Khan N, Rama Krishna G, Sheikh JA, Rajagopal K, Agrewala JN. Prime-boost vaccination strategy with BCG and liposomized Acr1 reinvigorates BCG potency. Clin Exp Immunol. 2015;181(2):286-96.

10. Gowthaman U, Singh V, Zeng W, Jain S, Siddiqui KF, Chodisetti SB, Gurram RK, Parihar P, Gupta P, Gupta UD, et al. Promiscuous peptide of $16 \mathrm{kDa}$ antigen linked to Pam2Cys protects against Mycobacterium tuberculosis by evoking enduring memory T-cell response. J Infect Dis. 2011;204:1328-38.

11. Chodisetti SB, Gowthaman U, Rai PK, Vidyarthi A, Khan N, Agrewala $\mathrm{JN}$. Triggering through Toll-like receptor 2 limits chronically stimulated T-helper type 1 cells from undergoing exhaustion. J Infect Dis. 2015;211:486-96.

12. Jackson DC, Lau YF, Le T, Suhrbier A, Deliyannis G, Cheers C, Smith C, Zeng W, Brown LE. A totally synthetic vaccine of generic structure that targets Toll-like receptor 2 on dendritic cells and promotes antibody or cytotoxic T cell responses. Proc Natl Acad Sci USA. 2004;101:15440-5.

13. Jackson DC, Drummer HE, Brown LE. Conserved determinants for $\mathrm{CD} 4+\mathrm{T}$ cells within the light chain of the $\mathrm{H} 3$ hemagglutinin molecule of influenza virus. Virology. 1994;198:613-23.
14. Sharma N, Agrewala JN. Potent role of vaccines prepared from macrophages infected with live bacteria in protection against Mycobacterium tuberculosis and Salmonella typhimurium infections. I Infect Dis. 2004;190:107-14.

15. Scanga CA, Bafica A, Feng CG, Cheever AW, Hieny S, Sher A. MyD88deficient mice display a profound loss in resistance to Mycobacterium tuberculosis associated with partially impaired Th1 cytokine and nitric oxide synthase 2 expression. Infect Immun. 2004;72:2400-4.

16. Jayaraman P, Sada-Ovalle I, Nishimura T, Anderson AC, Kuchroo VK, Remold HG, Behar SM. IL-1 $\beta$ promotes antimicrobial immunity in macrophages by regulating TNFR signaling and caspase-3 activation. J Immunol. 2013;190:4196-204.

17. Khader SA, Bell GK, Pearl JE, Fountain JJ, Rangel-Moreno J, Cilley GE, Shen F, Eaton SM, Gaffen SL, Swain SL, et al. IL-23 and IL-17 in the establishment of protective pulmonary CD4 $+\mathrm{T}$ cell responses after vaccination and during Mycobacterium tuberculosis challenge. Nat Immunol. 2007:8:369-77.

18. Khader SA, Cooper AM. IL-23 and IL-17 in tuberculosis. Cytokine. 2008:41:79-83.

19. Djuardi Y, Sartono E, Wibowo H, Supali T, Yazdanbakhsh M. A longitudinal study of BCG vaccination in early childhood: the development of innate and adaptive immune responses. PLoS ONE. 2010;5(11):e14066.

20. de Cassan SC, Pathan AA, Sander CR, Minassian A, Rowland R, Hill AV, McShane H, Fletcher HA. Investigating the induction of vaccine-induced Th17 and regulatory T cells in healthy, Mycobacterium bovis BCG-immunized adults vaccinated with a new tuberculosis vaccine, MVA85A. Clin Vaccine Immunol. 2010;17:1066-73.

21. Lu M, Xia ZY, Bao L. Enhancement of antimycobacterial Th1-cell responses by a Mycobacterium bovis BCG prime-protein boost vaccination strategy. Cell Immunol. 2013;285:111-7.

22. Forbes EK, Sander C, Ronan EO, McShane H, Hill AV, Beverley PC, Tchilian EZ. Multifunctional, high-level cytokine-producing Th1 cells in the lung, but not spleen, correlate with protection against Mycobacterium tuberculosis aerosol challenge in mice. J Immunol. 2008;181:4955-64.

23. Aagaard C, Hoang T, Dietrich J, Cardona PJ, Izzo A, Dolganov G, Schoolnik GK, Cassidy JP, Billeskov R, Andersen P. A multistage tuberculosis vaccine that confers efficient protection before and after exposure. Nat Med. 2011;17:189-94.

24. Li J, Huston G, Swain SL. IL-7 promotes the transition of CD4 effectors to persistent memory cells. J Exp Med. 2003;198:1807-15.

25. Siddiqui KF, Amir M, Gurram RK, Khan N, Arora A, Rajagopal K, Agrewala JN. Latency-associated protein Acr1 impairs dendritic cell maturation and functionality: a possible mechanism of immune evasion by Mycobacterium tuberculosis. J Infect Dis. 2014;209:1436-45.

26. Mogensen TH. Pathogen recognition and inflammatory signaling in innate immune defenses. Clin Microbiol Rev. 2009;22:240-73.

27. Chan ED, Chan J, Schluger NW. What is the role of nitric oxide in murine and human host defense against tuberculosis?Current knowledge. Am J Respir Cell Mol Biol. 2001;25:606-12.

28. Tak PP, Firestein GS. NF-kappaB: a key role in inflammatory diseases. J Clin Invest. 2001;107:7-11.

29. Rowland R, McShane H. Tuberculosis vaccines in clinical trials. Expert Rev Vaccines. 2011;10:645-58

30. Ottenhoff TH, Kaufmann SH. Vaccines against tuberculosis: where are we and where do we need to go? PLoS Pathog. 2012;8:e1002607.

31. Dietrich J, Lundberg CV, Andersen P. TB vaccine strategies-what is needed to solve a complex problem? Tuberculosis (Edinb). 2006;86:163-8.

32. Dey B, Jain R, Gupta UD, Katoch VM, Ramanathan VD, Tyagi AK. A booster vaccine expressing a latency-associated antigen augments BCG induced immunity and confers enhanced protection against tuberculosis. PLoS ONE. 2011;6:e23360.

33. Hougardy JM, Place S, Hildebrand M, Drowart A, Debrie AS, Locht C, Mascart F. Regulatory T cells depress immune responses to protective antigens in active tuberculosis. Am J Respir Crit Care Med. 2007;176:409-16.

34. Jaron B, Maranghi E, Leclerc C, Majlessi L. Effect of attenuation of Treg during BCG immunization on anti-mycobacterial Th1 responses and protection against Mycobacterium tuberculosis. PLoS ONE. 2008;3:e2833.

35. Bhattacharya D, Dwivedi VP, Kumar S, Reddy MC, Van Kaer L, Moodley P, Das G. Simultaneous inhibition of T helper 2 and T regulatory cell differentiation by small molecules enhances Bacillus Calmette-Guerin vaccine efficacy against tuberculosis. J Biol Chem. 2014;289:33404-11. 
36. Gurram RK, Kujur W, Maurya SK, Agrewala JN. Caerulomycin A enhances transforming growth factor-beta (TGF-beta)-Smad3 protein signaling by suppressing interferon-gamma (IFN-gamma)-signal transducer and activator of transcription 1 (STAT1) protein signaling to expand regulatory T cells (tregs). J Biol Chem. 2014;289:17515-28.

37. Chang JH, Kim YJ, Han SH, Kang CY. IFN-gamma-STAT1 signal regulates the differentiation of inducible treg: potential role for ROS-mediated apoptosis. Eur J Immunol. 2009;39:1241-51.

38. Ulloa L, Doody J, Massague J. Inhibition of transforming growth factorbeta/SMAD signalling by the interferon-gamma/STAT pathway. Nature. 1999:397:710-3.

39. Lighvani AA, Frucht DM, Jankovic D, Yamane H, Aliberti J, Hissong BD, Nguyen BV, Gadina M, Sher A, Paul WE, O'Shea JJ. T-bet is rapidly induced by interferon-gamma in lymphoid and myeloid cells. Proc Natl Acad Sci USA. 2001;98:15137-42.

40. Mizobuchi T, Yasufuku K, Zheng Y, Haque MA, Heidler KM, Woods K, Smith GN Jr, Cummings OW, Fujisawa T, Blum JS, Wilkes DS. Differential expression of Smad7 transcripts identifies the CD4 + CD45RChigh regulatory $T$ cells that mediate type $V$ collagen-induced tolerance to lung allografts. J Immunol. 2003:171:1140-7.

41. Drennan MB, Nicolle D, Quesniaux VJ, Jacobs M, Allie N, Mpagi J, Fremond C, Wagner H, Kirschning C, Ryffel B. Toll-like receptor 2-deficient mice succumb to Mycobacterium tuberculosis infection. Am J Pathol. 2004; 164:49-57.

42. Harding CV, Boom WH. Regulation of antigen presentation by Mycobacterium tuberculosis: a role for toll-like receptors. Nat Rev Microbiol. 2010;8:296-307.

43. Herbst S, Schaible UE, Schneider BE. Interferon gamma activated macrophages kill mycobacteria by nitric oxide induced apoptosis. PLoS ONE. 2011;6:e19105.

44. Bekker LG, Freeman S, Murray PJ, Ryffel B, Kaplan G. TNF-alpha controls intracellular mycobacterial growth by both inducible nitric oxide synthase-dependent and inducible nitric oxide synthase-independent pathways. J Immunol. 2001;166:6728-34.

45. Sallusto F, Lanzavecchia A. Human Th17 cells in infection and autoimmunity. Microbes Infect. 2009;11:620-4

\section{Submit your next manuscript to BioMed Central and we will help you at every step:}

- We accept pre-submission inquiries

- Our selector tool helps you to find the most relevant journal

- We provide round the clock customer support

- Convenient online submission

- Thorough peer review

- Inclusion in PubMed and all major indexing services

- Maximum visibility for your research

Submit your manuscript at www.biomedcentral.com/submit 